\title{
Gender Ambiguity, Domesticity and The Public Space: The Case of Wilkie Collins's The Woman in White
}

\author{
Debora Antonietta Sarnelli \\ Department of Humanities, University of Salerno, Salerno, Italy
}

Email address:

dsarnelli@unisa.it

\section{To cite this article:}

Debora Antonietta Sarnelli. Gender Ambiguity, Domesticity and The Public Space: The Case of Wilkie Collins's The Woman in White. English Language, Literature \& Culture. Vol. 5, No. 3, 2020, pp. 116-123. doi: 10.11648/j.ellc.20200503.17

Received: September 1, 2020; Accepted: September 23, 2020; Published: October 12, 2020

\begin{abstract}
Starting from Linda Brannon's "the Doctrine of Two Spheres" (Brannon 2004) and Barbara Welter's "the Cult of True Womanhood" (Welter 2000), the contribution aims at analyzing how the "Doctrine of Two Spheres" is clearly visible in Wilkie Collins's The Woman in White (1859), where the main protagonists' personalities and behaviors reveal both the preservation and subversion of the separate spheres ideology. The novel is shaped around the dichotomy between two half-sisters, that embody two contrasting forms of femininity. Laura epitomizes the Angel in the House, Marian, by contrast is a liminal figure, characterized by gender ambiguity. She is masculine in her physical appearance and in her behaviors. She constantly moves between gender roles and between the public and domestic space. Similarly, the two male protagonists of the novel, Walter and Count Fosco, are at the antipodes of each other. Walter, after a 'bildung journey' towards masculinity, acquires the typical masculine attributes of a Victorian man. Count Fosco, like Marian, is characterized by gender ambiguity. $\mathrm{He}$ moves between gender roles, disclosing feminine features and cherishing ladylike habits. In the end, Fosco and Marian's gender ambiguity is punished with death: death by assassination for the villain, symbolic and social death for Marian the spinster, thus re-establishing Victorian gender roles.
\end{abstract}

Keywords: Gender Ambiguity, Domesticity, Womanhood, Sensationalism, Victorianism

\section{An Introduction to the Doctrine of Two Spheres}

The increasing effects of industrialism and the consequent growing urbanism changed the Victorian perception of spaces. In particular, the strong industrialization that characterized the years of Queen Victoria's reign resulted in a clear-cut split between private and public spaces. The constant social changes and the separation of work in the rapidly expanding industrialized cities led to men and women forcing "to adapt to different environments and roles" [1], with men working outside of the house whereas women oversaw the household. While before the 19th century, in a pre-industrial society, both men and women were mostly living on farms and working together, the industrialization "changed the lives of a majority of people in Europe and North America by moving men outside the home to earn money" [1]. With the end of a family-based economy and the consequent growth of the market economy, women had to devote their time looking after the home and the children.

The separation of public and private spaces resulted in a separation between masculine versus female spaces. Certainly, this binary separation became widely associated with gender, placing women in the private sphere of the home and men in the public and urban-oriented domain of employment and business. Linda Brannon calls this separation "the Doctrine of Two Spheres" [1] that she associates to the historian Barbara Welter's "the Cult of True Womanhood", an ideal of femininity prevalent among the upper and middle classes, that came into existence between 1820 and 1860 [2]. True women, as Welter discusses, were judged on four cardinal attributes: "piety, purity, submissiveness, and domesticity" [2]. Domesticity, in particular, was regarded as an admirable quality as the home was thought to be the woman's proper sphere: "The true woman's place was unquestionably by her own fireside-as daughter, sister, but most of all as wife and mother" [2]. The woman's mission was to maintain the house a cozy place for men to find comfort and solace after a day of hard work in 
the public space. Victorians praised the tranquility of well-run middle class households under the moral guide of middle class 'true women', who were supposed to devote themselves exclusively to unpaid domestic responsibilities and childcare, a condition that distinguished them from those women belonging to the working class, as living on a single wage was, for the latter, quite hard. Domesticity was a privilege. Spending time at home with the children, managing the economy of the house were honors that kept middle class women away from the man-oriented labor market that clashed with the attributes of domesticity.

The philosophy of domesticity was the hallmark of middle-class life. It was favorably praised by domestic manuals, pamphlets and magazines addressed to middle class women. Kay Boardman discusses how Victorian magazines attest to the Victorians' preoccupation with domesticity and the private. Among them, Boardman recollects two magazines, The Ladies' Treasury and The Englishwoman's Domestic Magazine that explicitly celebrated the domestic life and the middle-class femininity, providing advice of how to properly run the home economy [3]. Magazines praised those skills necessary for running middle-class households and at the same time consolidated the cult of domesticity. As Emily Allen asserts, Victorian middle class women were strongly connected to the realm of domesticity. They were "the angels in the house" responsible for domestic concerns, including childcare [4]. Marriage and motherhood were their fulfilments and highest achievements and believed to be their only source of happiness [4]. Brannon, in this regard, defines Victorian middle-class women as "passive, dependent, pure, refined, and delicate" [1]. Men, by contrast, were supposed to be "active, independent, coarse, and strong" [1], as the creation of the two opposite spheres did not only have a social effect on women. In the Victorian era, also men had to face great expectations of manliness. This gender-based division of spaces reinforced the belief, so common during the Victorian era, of the patriarchal family as the most important social unit, and, moreover, as the most convenient one for the growth of the nation.

\section{The Case of Wilkie Collins's The Woman in White}

\subsection{The Sensation Novel}

The "Doctrine of Two Spheres" is clearly visible in Wilkie Collins's novel The Woman in White (1859), "of all sensation novels considered the best and best known" [5], where the main protagonists' personalities and behaviors reveal both the preservation and subversion of the separate spheres ideology. The Woman in White, generally acknowledged as the first sensation novel, plays with and transgresses, in some respects, the Victorian ideals of gender roles. The work first appeared in serial form in Dickens' All the Year Round between the end of 1859 and August 1860, marking the beginning of the sensation literature [6]. Collins's novel, as Stephen Knight argues, "caused a sensation in modern terms - readers besieged the shops, there were 'Women in White' fashions, tea-rooms, merchandise of all kinds" [7]. Like Gothic fiction, the sensation literature aimed at stimulating the readers' emotions and senses, a literature that D. A. Miller, in his influential study "Cage Aux Folles: Sensation and Gender in Wilkie Collins's The Woman in White", describes as addressing itself "primarily to the sympathetic nervous system, where it grounds its characteristic adrenaline effects: accelerated heart rate and respiration, increased blood pressure, the pallor resulting from vasoconstriction, etc. [5]."

As "the literary expression of an age of 'events' and of the society of the spectacle" [6], the sensation novel, Lyn Pykett argues, often exploited those scandals that sold newspapers, such as violent death, divorce, poisoning, adultery and bigamy, hinting that such crimes could be plotted by the person next door. Sensation novelists wrote about subjects that would appeal to the "downright depraved tastes" [8] of the Victorians, as a response to the public's avid craving and continuous demand for sensation [8]. The scandal subjects the sensation novel addressed, through a combination of gothic elements with domestic ones, earned it the reputation of a dangerous genre, a perilous threat to the social order, capable of disturbing gender roles, moral codes, beliefs and conventions. The belief about the genre's corrupting influence on the morals was mostly due to the fact that the sensation novels faced topics that respectable Victorians considered scandalous and unmoral. Furthermore, the accent on bodily sensations such as fear, excitement and on sexuality contributed to the bad reputation sensation novels had, as pernicious assault to the Victorian middle-class respectability.

Likewise, the sensation novel was criticized to contravene, in some respects, the woman's expected role within the society, as it often portrayed strong women who transgress gender roles and disclose masculine physical traits, bravery and fearlessness that, in Victorian times, were supposed to be male prerogatives. This is the case with Marian Halcombe the most prominent female character in Collins's The Woman in White, who, as Ann Gaylin points out, represents "transgression of the unwritten laws of proper female behavior" [9]. She could be considered, as Michael Diamond suggests, "the first of a line of strong women in sensational fiction" [10] capable of facing risks and of solving riddles. For Lyn Pykett "Marian's proto-feminist pronouncements and her active involvement in rescuing Laura and helping Walter to restore her half-sister's identity" are Collins's "way of questioning and challenging current gender roles" [11]. The connection between sensation literature and gender roles is discussed by Tara MacDonald. The critic has argued that the sensation fiction "playful engagement with human complications and misconceptions" [12] in novels such as Collins's The Woman in White, where Marian Halcombe is depicted as a masculine woman, demonstrates that sensation literature is a genre concerned with "disrupt [ing] gender conventions and challeng [ing] stable notions of identity" [12]. According to Pykett "most of Collins's novels explored the way in which gender roles were constructed, and, at the same time, explored various pressures for and anxieties about changes in gender roles in the 
mid-nineteenth century" [11] and "offered a critique of the class and gender hierarchies of Victorian society" [11]. The Woman in White is one of those novels to which Pykett refers to and Collins uses his unconventional heroine Marian Halcombe to serve his purposes.

\subsection{The Angel in the House Versus the Androgynous Woman}

The Woman in White is shaped around the dichotomy between two half-sisters, that embody two contrasting forms of femininity. The attractive Laura Fairlie unveils those features that Victorians associated with the archetype of the Angel in the House. She discloses all the attributes that Barbara Welter attributes to the Victorian true woman: "piety, purity, submissiveness, and domesticity" [2]. She uncovers the typical purity of childhood, she is delicate, obedient, always in need of protection and about to marry the man her father approved of before his death. She is presented to the readers through Walter Hartright's eyes, the novel's hero and one of its multiple narrators. She is "A fair, delicate girl, in a pretty light dress [...] with truthful innocent blue eyes" [13]. While his words might accurately be used to describe a child, Laura is twenty years old when the narration is opened, only a few months from legal adulthood. With her fragile and angelic appearance and her "simple muslin dress" [13] Laura typifies the Victorian Angel in the House. By contrast, Marian Halcombe, her half-sister, exhibits a stark contrast to Laura's purity, asserting her personality outside of the boundaries imposed by Victorian gender roles. Upon arriving at the Fairlie household, Walter, a drawing master employed by the wealthy Mr. Fairlie to tutor the two half-sisters, meets Marian first. He enters the breakfast room while she is looking outside the window and takes the opportunity to make an accurate study of her figure. He "was struck by the rare beauty of her forms" observing from a distance that "her figure was tall, yet not too tall; comely and well-developed, yet not fat; her head set on her shoulders with an easy, pliant firmness; her waist, perfection in the eyes of a man, for it occupied its natural place" [13]. The way Walter describes the woman may encourage the reader to believe that he will eventually fall in love with Marian. Her body fits Walter's expectation of female beauty. However, his expectations fail when Marian "approached nearer" [13] making her face visible: "The lady is ugly!" [13]. His description of Marian suddenly changes, "the fair promise of a lovely figure" [13] disappears, and his eyes lay on "the face and head that crowned it. The lady's complexion was almost swarthy, and the dark down on her upper lip was almost a moustache. She had a large, firm, masculine mouth and jaw; prominent, piercing, resolute brown eyes; and thick, coal-black hair, growing unusually low down on her forehead. Her expression - bright, frank, and intelligent - appeared, while she was silent, to be altogether wanting in those feminine attractions of gentleness and pliability, without which the beauty of the handsomest woman alive is beauty incomplete" [13].

Walter is shocked by the sharp contrast between Marian's lovely body and her masculine face. He points out the unfeminine traits he ascribes to her jaw, her upper lip and her open gaze. Because he has assumed an aesthetic standard of femininity, he has a certain expectation for her face, due to the feminine forms he has already noticed and appreciated: "The easy elegance of every movement of her limbs and body as soon as she began to advance from the far end of the room, set me in a flutter of expectation to see her face clearly" [13]. He expects continuity from the ladylike grace he has admired in her body, but the stark opposition of her face destroys his hopes. When first meeting Walter, Marian describes herself as "dark and ugly ... crabbed and odd" [13] while she defines Laura "fair and pretty ... sweet-tempered and charming" [13]. The dissimilarity between the two half-sisters is a matter of fact: Marian is cheeky, resolute and dynamic, Laura, by contrast, is sensitive, ingenuous and static. The dissimilarity between the two is mostly evident in terms of beauty. Laura embodies Walter's female ideal of beauty. As a result, he falls in love with her. He describes her through a water-color drawing he has previously made of her, as if she were a work of art, focusing on her delicate face. Rather than a real character, Laura seems to be part of the picture he is observing, and she appears as an idealized Madonna, the personification of the Angel in the House through Walter's masculine gaze. It is as if Walter the artist had painted her according to his expectations. She is perfect the way she is, with those eyes "of that soft, limpid, turquoise blue, so often sung by the poets, so seldom seen in real life" [13]. The reader understands that Laura's outstanding beauty will inflame Walter's heart and Walter, on his side, has been farsighted, since Laura, besides being the most beautiful, is also the richest one between the two half-sisters.

The dichotomy between Marian and Laura becomes more evident when a series of vicissitudes, linked to the mysterious woman in white of the title, discloses their real characters. The ghostly figure of the woman in white unveils an uncanny resemblance to Laura. Walter meets the mysterious woman at midnight at a crossroad on the outskirts of London, the night before his arrival at the Fairlie household. The encounter sets the wheels of the novel's plot in motion. The mysterious woman has just escaped from a private asylum. The woman's destiny, whose name is later discovered to be Anne Catherick, one of Mrs. Fairlie's old acquaintances, is intertwined with Laura's and the resemblance between the two ladies shocks Walter. After the first day spent as the sisters' drawing master, Walter suddenly notices Laura in a new way, as "a white figure, alone in the moonlight; in her attitude, in the turn of her head, in her complexion, in the shape of her face, the living image, at that distance and under those circumstances, of the woman in white!" [13].

Once Walter associates Laura the heiress to Anne the madwoman - later to be discovered as half-sisters - the plot plays with their physical likeness and inclination to perform the gender roles assigned to them. Anne Catherick's flawless accomplishment of her gender role enables her to escape from the asylum as she herself admits to Walter, when the two meet at Mrs. Fairlie's tomb: "It was easy to escape, or I should not have got away. They never suspected me as they suspected the 
others. I was so quiet, and so obedient, and so easily frightened" [13]. From then on, she resumes wearing entirely white clothes, because Laura's mother, Mrs. Fairlie, had once told her "little girls of her complexion looked neater and better in all white than in anything else" [13] and passed on to her "Laura's old white frocks and white hats" [13]. Jenny Bourne Taylor asserts that, "What is weird about Anne is her obedience and docility, her perpetual childlikeness," which "suggests the pathologization of feminine passivity" [14]. By wearing the white clothes reminiscent of her childhood, Anne, who is almost two years older than Laura and already legally an adult woman, positions herself permanently as a little girl.

The connection between womanhood and childhood is, again, epitomized in the person of Laura Fairlie. For Walter, she discloses "the innocent perplexity of a child" [13]. In one of her diary entries, Marian defines Laura "the poor child" with "pure hearth and that innocent mind" [13] and, in another entry, she writes "the gentle, innocent, affectionate creature" [13], thus using, when referring to Laura, adjectives commonly associated with childhood. For Count Fosco, Laura's innocence and purity are "admirable sentiments, and I have seen them stated at the tops of copy-books" [13], and when referring to her, he claims women "are nothing but children grown up" [13]. Laura is often treated like a child. Marian, more than her sister, seems to play the role of her protector and, in more than one occasion, of both her mother and her father. Marian's actions are circumscribed to protect and preserve "Laura's honour, Laura's happiness - Laura's life itself' [13]. After Walter and Laura fall in love, Marian is the one who tells him to leave Limmeridge House for Laura's sake, taking on the role of a male family member. Laura is engaged to be married and the reciprocated love for her drawing master has inevitably altered the feelings towards her future husband, Sir Percival Glyde. Marian, as D. A. Miller as noted, acts as an intermediary between Laura and the male figures of the novel [5]. Marian is the one who writes to the family solicitor about the matter of a signature Sir Percival required from Laura (a fraudulent means to access her fortune). Marian, again, confronts Sir Percival when he locks Laura up in her room, thus threating him to appeal to those "laws in England" that "protect women from cruelty and outrage" [13]. The image of an innocent, childlike Laura endures in all the novel. Mr. Gilmore, the faithful family solicitor, sees in Laura "a desperate clinging to the past" [13], when she was "the liveliest, happiest child that ever laughed the day through" [13]. When discussing with Mr. Gilmore the marriage-settlement to Sir Percival Glyde, Laura bursts into tears and the solicitor tries to calm her down "as if she had been the little Laura Fairlie of ten years ago" [13]. After her escape from the deceitful imprisonment in the asylum, Marian and Walter act out as Laura's parents, trying to amuse her "with children's games at cards, with scrap-books full of prints" [13]. The shock of the months spent in the asylum increases her childlike innocence: "She spoke as a child might have spoken, she showed me her thoughts as a child might have shown them" [13]. In the end, when Laura recovers herself from the trauma of her stolen identity and her fraudulent confinement in the asylum, her "growing self-possession", to quote Jenny Bourne Taylor, "is marked by her realization that she is economically and sexually powerless and treated like a child" [14].

Her belonging to the bounded space of the house and her consequent resolution to put aside her passions for Walter and adhere to the role society - in the symbol of her dead father has assigned to her, increase Laura's fragility and vulnerability. The static role she is given, that of the Angel in the House, enables the villains of the narrative, Sir Percival and Count Fosco, to manipulate her identity. Rather than the heroine of the novel, she is depicted as the victim, whose culturally-defined role reinforces her submissiveness. As the personification of the Angel in the House, Laura shows her naturally self-sacrificial spirit: she marries the man to whom her father promised her on his deathbed rather than Walter, the man she really loves. She does not complain, but sacrifices herself in the memory of her father and acts the part of the dutiful and virtuous wife, as she is expected to do. Deprived of both her wealth and her identity and expelled from the domestic sphere where she has always lived, Laura is completely abandoned and incapable of saving herself in the public domain she has never faced before. Marian first, and then Walter will rescue her from the outrageous and miserable fate Sir Percival and Count Fosco have planned for her. Her impeccable performance of the role of the Victorian wife facilitates the villains in their evil plans and increases her vulnerability. The lack of an independent identity outside of the culturally-defined role ascribed to her, aids Laura's imposed transformation into Anne Catherick. Robbed of both her name and of her own identity, Laura learns at her own expenses that outer appearances do not always match someone's real identity.

Whereas Laura epitomizes the Victorian Angel in the House, Marian, by contrast, questions and, in more than one occasion, transgresses Victorians' idea of womanhood. Ann Gaylin associates her to liminality, to a state of inbetweeness, as a liminal figure she moves between gender roles, but, also, between the domestic and the public space. As Walter has noticed, Marian verges on being outright masculine in her looks, and this masculinity is also mirrored in her behaviors. She is "resolute" [13] with a "fearless face" [13], she likes chess and backgammon, while she fails at typically female things like play the piano or draw, her sister's favorite diversions: "Drawing is her favourite whim, not mine ... I waste paint and spoil paper, for her sake ... Miss Fairlie plays delightfully. For my own poor part, I don't know one note of music from the other; but I can match you at chess, backgammon, écarté, and ... even at billiards as well" [13]. The pastimes Marian informs Walter she has mastered involve mental skills women are not assumed to possess.

Throughout the novel, the reader is reminded repeatedly of Marian's male features: on shaking hands with Walter before his abrupt departure, he claims she has got "the strong, steady grasp of a man" [13]; her tears "come almost like men's tears" [13]; her hands "always were, and always will be, as awkward as a man's [13]; she carries "a horrid heavy man's umbrella 
[13]; and, sometimes, she imagines herself as a man: "If I had been a man, I would have knocked him down on the threshold of his own door, and have left his house, never on any earthly consideration to enter it again. But I was only a woman" [13]. Count Fosco admires Marian since "she has the foresight and resolution of a man" [13] and she is "firm as a rock" [13]. Throughout the narration, the Count seems to acquire an erotic attraction towards Marian, while Marian, on her side, is afraid of him but at the same time suffers his undeniable charm: "The man has interested me, has attracted me, has forced me to like him" [13]. Despite the lack of physical beauty, Marian discloses an inner beauty of soul, as she devotes entirely her life to helping her younger sister. The willingness to sacrifice her life for her sister's sake makes Marian the real heroine of the story.

Marian does not back down when the circumstances require her to act like a man, as the "two women had neither father nor brother to come to the house" and take their parts [13]. She is willing to perform dangerous actions and face perilous risks for Laura's happiness. She climbs on the roof of the veranda of Sir Percival's mansion, Blackwater Park, in the middle of a rainy night to overhear a conversation taking place in the library between the Count and Sir Percival. She removes her feminine clothes that are too heavy for the climbing and could betray her, and climbs on the veranda top. The abundant clothes, emblem of the constrictions Victorian women had to follow, limit her mobility. Their removal becomes Marian's refusal of the gender role society ascribes to women. Freed from her clothes/social restrictions, Marian moves in the dark, sits in the rain, motionless, and eavesdrops Percival and Fosco's plans to get, illegally, Laura's money. Nina Auerbach believes Marian is "fiction's first female detective, and she is certainly the most versatile, for in addition to skill as acrobat and eavesdropper she gains salient information in oracular dreams and trances. In fact, Collins can prevent her physical and mystical prowess from ending the novel prematurely only by striking her down with a violent illness just as she is about to spoil the suspense" [15].

As the ancestor of the female detective, Marian is brave enough to climb onto the veranda and, as Ann Gaylin stresses, she "arrogates to herself the male privileges of mobility" [9]. She transcends traditional feminine gender expectations and takes a decision that positions her outside of women's expected behaviors. Before that, she has already shown her ability as a detective, acting as one in more than one occasion. She follows the mysterious foot-steps around the boat-house an afternoon when she is looking for Laura. She searches among her late mother's letters for clues about the connection between Mrs. Fairlie and the woman in white. She delivers letters and overhears several conversations taking place at Blackwater Park. She makes inquiries about Laura's incongruous death and, last but not least, the support she gives Walter during the investigations he leads to uncover the two criminals turns out to be invaluable for the hero's victory. Her secret mission on the veranda roof is the extreme act that sanctions her role as the foremother of those women detectives that would soon become popular. However,
Marian's nocturnal expedition on the roof triggers a serious illness which leaves her feverish and weakened for most of the remaining pages of the novel. Her transgression of a woman's position in society is punished with an unexpected illness, that excludes her from the games. She has ventured too far from the Victorian norm. It is this last act of bravery that sanctions the beginning of her transformation into a silent Angel in the House. By going out of the mansion right on the roof top, she has crossed the boundary between gender roles. It is Count Fosco, when violates the privacy of her diary by adding a postscript to it, who informs the reader about her state of health. According to Miller, Fosco's double violation of the diary is to be considered a virtual rape [5]. The retreat of his unfeminine heroine allows Collins to employ other characters in the function of the narrator and, also, to give Walter his voice back, re-establishing gender roles.

\subsection{The Bildung Journey Towards Masculinity}

For his part, Walter must prove to have become a real man, according to Victorian standards of masculinity, through the vicissitudes he suffered while in Central America. As it was unacceptable at that time for a man to have feminine characteristics, Walter must abandon the domestic space where he works as a drawing master and eventually face the male-oriented public space to become the hero of the novel. When the reader is first introduced to Walter, he has not become a real man yet. As Miller argues, the nervousness, "a signifier of femininity" [5] that Walter experiences when he first meets the mysterious woman in white reveals a feminine side that he works hard to suppress throughout the rest of the novel. It is, for Miller, the unexpected touch of the woman in white that infects Walter, feminizing him. Miller, at this stage, defines Walter "unformed" [5], in the sense that his masculinity is still not totally achieved. In this regard, examining his position at the outset of the novel, Jenny Bourne Taylor defines him a "domesticated artist" [14] that appears as "a male governess figure" [14]. Walter says of himself: "I have long since learnt to understand, composedly and as a matter of course, that my situation in life was considered a guarantee against any of my female pupils feeling more than the most ordinary interest in me, and that I was admitted among the most beautiful and captivating women, much as a harmless domestic animal is admitted among them" [13].

It is his role as a drawing master in a socially-defined feminine environment that renders him unmanly. He works among young ladies in the coziness of middle-class households, away from the public space, where men are supposed to belong. When he falls in love with Laura it is his lack of masculinity that makes him unfit for his role as the story's hero and, as a consequence, as her husband. As Miller points out, Walter grows out of his effeminate nervousness to be a man and conquers his role as the novel's hero after he survives "plague, pygmy arrows, and shipwreck in Central America" [5]. Forced to leave Limmeridge House because of his inappropriate feelings towards Laura, he sails for Honduras in a private expedition "to make excavations among 
the ruined cities of Central America" [13] a "self-imposed exile" [13] that sanctions his maturation. Marian has a dream about him facing the most challenging obstacles: "The Pestilence that wastes, the Arrow that strikes, the Sea that drowns, the Grave that closes over Love and Hope, are steps of my journey, and take me nearer and nearer to the End" [13]. The end will be the reconciliation with the woman he loves. Now a real man, he can vindicate Laura's name by facing the "poisonous" [13] Count Fosco and the scoundrel Sir Percival. Although Walter, once back from America, devotes his life to gathering clues to prove and dismantle the wicked plan of the two villains, it is not his hand that avenges the beautiful Laura. Other factors contribute to Fosco and Percival's punishment. It is the past that, in both cases, comes back to punish them of their deeds. Sir Percival, an illegitimate fortune hunter who has secretly forged his parents' marriage certificate to give himself the false title of the Baronet of Blackwater, dies in a fire while trying to erase the evidence of his forgery. Count Fosco, the more intelligent and self-controlled of the duo, is stabbed by a hitman hired by an Italian Secret Society he has betrayed.

Having restored Laura's identity, Walter's perilous 'bildung journey' towards masculinity is eventually rewarded with Laura's love and property and, to quote Miller, with a "submissive Victorian wife" [5]. Laura is ultimately re-established to the space where she, as a Victorian woman, belongs: the domestic sphere, returning to her family house. The novel's happy ending re-establishes a typical Victorian family: Laura and Walter's marriage, their establishment at Limmeridge House and the birth of a son sanction the end of the novel, the way the readers of that time expected. According to Leila Silvana May, this final successful family was born out of the "sisterly love" between Marian and Laura [16].

\subsection{Marian and Fosco's Gender Ambiguity}

Walter and Laura act out typical Victorian gender roles, while the other relevant characters of the story, Marian Halcombe and Count Fosco, assert their personalities outside of traditional gender roles. Laura and Walter's archetypical gender roles are epitomized, respectively, in the womanly "patience" and manly "resolution" addressed in the Preamble: "This is the story of what a Woman's patience can endure, and what a Man's resolution can achieve" [13]. Women must have "patience" and "endure", thus exemplifying their role as passive spectators with limited agency. Laura's patience and passivity is rewarded with a family of her own and a man she loves. Men, by contrast, must have "resolution" so that they can "achieve" great results. The Preamble echoes the Doctrine of Two Spheres: women at home as passive observers whereas men in the public space working and acting. The womanly patience is linked to stasis, while the manly resolution is associated with movement. Nina Auerbach reminds us that the Preamble's "poles of conventional masculinity and femininity are reasonably good introductions to Laura Fairlie, the nebulous, incompetent heroine, and her colorless suitor, Walter Hartright" [15].
In this regard, Richard Collins writes that Wilkie Collins "is careful to place each principal character along a continuum between masculine and feminine poles" so that "the wooden Walter and the anaemic Laura are poles of standard Victorian notions of gender ... by whom we measure the more interesting characters of mixed gender who transgress the usual boundaries and subvert Victorian standards" [17]. Those more interesting characters, to use Collins's words, are Marian and Count Fosco both characterized by a gender ambiguity. They move between femininity and masculinity, often crossing the boundaries between them. Marian discloses masculine traits, both in her physical appearance and in her behaviors, while the Count discloses feminine features and, also, he cherishes ladylike habits.

Richard Collins places Marian's disturbing moustache against a background of freak shows and medical studies of hermaphrodites that were common during the Victorian era. In this context, he defines Marian an "androgynous" woman [17] "that questioned and subverted Victorian notions of gender" [17]. Walter, the critic claims, is first attracted by Marian's femininity when he praises her gracious body, but he is soon disgusted by her masculinity, suggested by his shock at the sight of the dark moustache covering her upper lip. Similarly, Count Fosco oscillates between gender standards. He is effeminate in his tastes and amusements. He is addicted to sweets, hence when Sir Percival offers him some brandy the night the two are plotting against Laura, he prefers drinking water and sugar, leaving the Blackwater Park's master speechless: "Sugar-and-water for a man of your age!" [13]. Again, when he visits Mr. Fairlie at Limmeridge House, he lunches "entirely upon fruit-tart and cream" [13]. He adores small pets, such as white mice and birds, he "smiles at them, and kisses them, and calls them by all sorts of endearing names" [13]. His clothes are often bright-colored: "He had a broad straw hat on, with a violet-coloured ribbon round it" [13]. Last but not least, when Fosco sings Figaro's famous song in the Barber of Seville, he looks like "a fat St. Cecilia masquerading in a male attire" [13].

Fosco is fascinated by the resoluteness of "magnificent Marian" [13] and sees in her the most dangerous rival. His attraction for Marian, that he confesses as being "the one weak place in my heart ... the first and last weakness of Fosco's life" [13], appears as his only vulnerability. The one weakness he acknowledges in his closing recollection of the events has been his instinct to preserve her. He lets Marian and Laura escape him because of his sincere affection for Marian. The last words he addresses to Walter the night he leaves London are for Marian: "When I last saw Miss Halcombe she looked thin and ill. I am anxious about that admirable woman. Take care of her, sir! With my hand on my heart, I solemnly implore you, take care of Miss Halcombe!" [13]. Marian, on her side, hates the influence Fosco has on Sir Percival and the subtle and canny ways he uses to control her movements, concealed by the deceiving gentle manners he has towards the female characters. They both are, as Richard Collins asserts, the couple of true interest in the novel. As the antagonists of the novel's main characters, they denote those features that Laura 
and Walter do not possess. Fosco's wickedness contrasts with Walter's virtuousness while Marian's determination opposes Laura's inactivity and her masculine beauty, or better to say her ugliness, stands out against Laura's angelic look.

\subsection{Narrative Authority and the Female Voice}

Marian, unlike Laura who is completely denied a voice of her own, is one of the multiple narrators of the story. She uses her own voice to narrate the main events of the second epoch in the form of a diary, that same diary which will reveal itself to be crucial for Walter's mission to gain evidence against Sir Percival and the Count: "The first source of information to which I applied was the journal kept at Blackwater Park by Marian Halcombe" [13]. Despite being an engaging storyteller, Marian's role as a narrator is limited if compared to Walter. She is able to tell what happens from her personal point of view only when Walter is absent. Once the events shift from the domestic space to the male-oriented urban space, Marian's role as the detective is abruptly interrupted since her status as a woman cannot guarantee her the freedom of mobility she has had at Limmeridge House and at Blackwater Park.

Walter's return to England marks the end of her narration and, therefore, her point of view disappears to make room for Walter's. She loses her voice not to gain it again. Even when she rescues Laura from the asylum, she is denied the possibility to recollect that episode in her own words. This important moment of sisterly help is merely resumed by Walter in a few words in the third epoch: "I shall relate both narratives, not in the words (often interrupted, often inevitably confused) of the speakers themselves, but in the words of the brief, plain, studiously simple abstract which I committed to writing" [13]. Once Marian has helped Laura to escape, her attempt to demonstrate the evil plan plotted by Sir Percival and Count Fosco fails when she is forced to confront herself with the male society. The uncle Mr. Fairlie refuses to believe that mad woman is his niece. The declaration of the proprietor of the asylum, the death certificate signed by the doctor, the confession of the tombstone and the legal advice from $\mathrm{Mr}$. Kyrle lead to one result. Marian, as a woman, has no means to help her sister regain her stolen identity. She is able to investigate the Count's plan as long as he remains at Blackwater Park, but the moment he leaves the domestic space, her investigations are interrupted as she has no space and no freedom in the public domain. In a world ruled by men, Marian must remain at home to do what "a woman's hands are fit for" [13] and looking after childlike Laura, leaving the investigation to Walter.

Walter, unlike Marian, covers the first and the last epoch of the story. As the first narrator to be introduced, he is given the privilege to present the characters from his personal point of view, or as Leah Henderson discusses, from his masculine gaze [18]. Marian, Henderson argues, "does not have the privilege to reciprocate this gaze upon Walter in her own diary entries" [18]. In this respect, Ann Gaylin convincingly argues that the female characters "have very different narrative opportunities than men do in the novel. Although it seems Marian and Walter contribute equally to solving the mystery,
Walter ultimately controls what is told to whom" [9]. It is Walter that filters the information before they are presented to the reader. The story "begins firmly in the male hand" [9] and is concluded by the same pen. By gaining control over the narrative, Walter also controls Marian. He brings back Marian to the domestic space, denying her narrative voice. Although her contribution to the novel's happy ending is undisputable, Marian is not allowed to face the Count in the last battle, because, as a woman, the role that is required from her is to stay at home and take care of Laura, the child. Marian begs Walter to allow her to accompany him to the Count's house, but he refuses. "Don't refuse me because I'm only a woman. I must go! I will go!" [13]. Walter assumes his role as a patriarchal figure, encouraging women association with the domestic space. For Ann Gaylin, in Walter's second narrative, Marian appears completely "femininized" [9].

Marian's gradual transformation from the brave masculine woman to the submissive Angel in the House becomes evident in the concluding remarks of the novel. The novel's traditional conclusion, with the marriage between Laura and Walter and the spinster Marian taking care of their son as the next heir of Limmeridge House, opposes with the idea that the reader has of Marian. Walter's total control of the narrative eventually domesticates the wild Marian. By asserting his narrative authority and, therefore, his role as the novel's hero, Walter silences Marian assigning to her the role of his son's governess. She, in the end, acquires that self-sacrificial spirit typical of the Angel in the House: she gives up the possibility to lead an independent life in order to support Laura in childcare and household running. Her gender ambiguity is, at last, punished with the tacit recognition and acceptance of the role women of her class had to follow and, therefore, with the symbolic death of Marian's real personality. After her outrageous deed on the veranda roof, Marian is gradually brought back to the domestic space never to leave it again.

Whereas Marian's “indeterminate status" [9] is punished with her symbolic and social death, Fosco's gender ambiguity is punished with death by assassination. He is assassinated and thrown in the Seine by the Italian Secret Society he has betrayed. The Brotherhood, the fictional name Walter gives to the Society, has his body marked in blood with a $\mathrm{T}$ for Traditore - that is, traitor. Marian's symbolic and social death, by contrast, inevitably makes her one of those surplus women that were regarded completely useless for the Victorian society. As Pamela Stone and Lisa S. Sanders [19] point out, Victorian spinsters were identified with the category of "superfluous" or "odd" women. They were believed to be unnatural as they failed to fulfill what was considered to be a woman's greatest achievement: to bear children. Spinsters had no place in Victorian society as they were unable to accomplish their domestic role, as wife and mother. As a result, those women who failed to support the growth of the nation were considered socially dead.

Marian the spinster has no other choice but to live at Limmeridge House with Laura and Walter, as she does not possess an income to support herself. The domestication of the masculine woman is eventually concluded when Walter 
identifies Marian with "the good angel of our lives" [13] and when Marian herself tacitly surrenders to the role that spinsters like her could carry out in Victorian families: the loving nanny. The closing fairy-like family portrait sanctions the hero's victory, his social and economic success and his new acquired role as the household master. Walter concludes his narrative by writing "let Marian end our story" [13]. He claims to give Marian the last words, but, in reality, as Miller points out, "what follows is dead silence" [5].

\section{Conclusions}

As discussed above, The Woman in White reveals both the preservation and subversion of the separate spheres ideology. In particular, the Doctrine of Two Spheres is clearly visible in the First and Third Epoch of Collins's novel. These two sections represent fixed gender ideologies. By contrast, the middle part, which is largely narrated by Marian, is characterized by a transgression of gender roles. The Second Epoch subverts the Doctrine of Two Spheres and women's association with domesticity through the figure of Marian Halcombe. As a liminal figure, she is characterized by gender ambiguity. She is masculine in her physical appearance and in her behaviors. She constantly moves between gender roles and between the public and domestic space. However, as Miller [5] and Gaylin [9] point out, these occasions of transgression inevitably disappear in the last part of the novel, where the Doctrine of Two Spheres returns in an irrepressible way. The conclusion re-establishes the typical Victorian gender roles, with men as industrious breadwinners dominating the public space, and women as their loyal helpmeets associated with domesticity. In the end, the characters that have transgressed their roles disclosing a gender ambiguity are punished with death: death by assassination for Fosco the villain, symbolic and social death for Marian the spinster.

\section{References}

[1] Brannon, Linda. "Gender Stereotypes: Masculinity and Femininity," in Gender: Psychological Perspectives. Boston: Pearson, 2004, pp. 159-185.

[2] Welter, Barbara. "The Cult of True Womanhood: 1820-1860". American Quarterly 18.2 (1966): 151-174.

[3] Boardman, Kay. "The Ideology of Domesticity: The Regulation of the Household Economy in Victorian's Women Magazines". Victorian Periodicals Review 33.2 (2000): 150-164.

[4] Allen, Emily. "Gender and Sensation," in Pamela K. Gilbert (ed.), A Companion to Sensation Fiction. Oxford: Blackwell, 2011, pp. 401-413.
[5] Miller, D. A. "Cage Aux Folles: Sensation and Gender in Wilkie Collins's The Woman in White". Representations 14 (1986): 107-136.

[6] Pykett, Lyn. "Collins and the Sensation Novel," in Jenny Bourne Taylor (ed.), The Cambridge Companion to Wilkie Collins. Cambridge: Cambridge University Press, 2006, pp. 50-64.

[7] Knight, Stephen. Crime Fiction 1800-2000. Detection, Death, Diversity. Basingstoke: Palgrave Macmillan, 2004.

[8] Pykett, Lyn. The Sensation Novel. From The Woman in White to The Moonstone. Plymouth: Northcote House, 1994.

[9] Gaylin, Ann. "The Madwoman Outside the Attic: Eavesdropping and Narrative Agency in The Woman in White". Texas Studies in Literature and Language 43.3 (2001): 303-333.

[10] Diamond, Michael. Victorian Sensation, Or, The Spectacular, the Shocking, and the Scandalous in Nineteenth-century Britain. London: Anthem Press, 2003.

[11] Pykett, Lyn. Wilkie Collins (Authors in Context). Oxford: Oxford University Press, 2009.

[12] MacDonald, Tara. "Sensation Fiction, Gender and Identity," in Andrew Mangham (ed.), The Cambridge Companion to Sensation Fiction. Cambridge: Cambridge University Press, 2013, pp. 127-140.

[13] Collins, Wilkie. The Woman in White. London: HarperCollins, 2001.

[14] Taylor, Jenny Bourne (1988). "The Woman in White: Resemblance and Difference-Patience and Resolution," in In The Secret Theatre of Home: Wilkie Collins, Sensation Narrative, and Nineteenth-Century Psychology. London: Routledge, pp. 98-130.

[15] Auerbach, Nina. "Old Maids and the Wish for Wings," in Woman and the Demon: The Life of a Victorian Myth. Cambridge, Mass: Harvard University Press, 1982, pp. 109-149.

[16] May, Leila Silvana. "Sensational Sisters: Wilkie Collins's The Woman in White". Pacific Coast Philology 30.1 (1995): 82-102.

[17] Collins, Richard. "Marian's Moustache: Bearded Ladies, Hermaphrodites, and Intersexual Collage in The Woman in White," in Maria K. Bachman and Don Richard Cox (eds.) Reality's Dark Light: The Sensational Wilkie Collins. Knoxville: University of Tennessee Press, 2003, pp. 131-172.

[18] Henderson, Leah. "Wilkie Collins and Oscar Wilde: Challenging Intersections Between the Male and Female Gaze in Victorian Popular Literature". FORUM: University of Edinburgh Postgraduate Journal of Culture \& the Arts 27 (2018): 1-11.

[19] Stone, Pamela K., Shapiro Sanders, Lise. Bodies and Lives in Victorian England: Science, Sexuality, and the Affliction of Being Female. New York: Taylor \& Francis Ltd, 2020. 